\title{
TERPENUHIKAH UNSUR PIDANA PENGUASAAN TANAH YANG SAMA- SAMA BELUM MEMILIKI SERTIFIKAT TANDA BUKTI HAK
}

\author{
EDWIN YULISKA \\ Sekolah Tinggi Ilmu Hukum Padang \\ edwinyuliska@gmail.com
}

\begin{abstract}
Law in Indonesia adheres to the Continental European legal system which is divided into two groups, namely the field of public law and the field of private law. Public law is a law that has a scope of legal subject to dispute with legal objects, namely state administration law, state administrative law, and criminal law. While private law is a field of law that has the scope of affairs of legal subjects that conflict with other legal subjects. But sometimes law enforcement often fails to understand these two legal systems, which cannot distinguish between criminal and civil ones, thus confusing civil cases that are made criminal cases and criminal cases used as civil cases for various reasons.
\end{abstract}

Keywords: criminal elements, land tenure, certificates

\begin{abstract}
Abstrak: Hukum di Indonesia menganut sistem hukum Eropa Kontinental yang dibagi ke dalam dua golongan, yakni bidang hukum publik dan bidang hukum privat. $\mathrm{H}$ ukum publik merupakan hukum yang memiliki ruang lingkup subjek hukum yang bersengketa dengan objek hukum yaitu hukum tata negara, hukum administrasi negara, dan hukum pidana. Sedangkan hukum privat merupakan bidang hukum yang memiliki ruang lingkup urusan subjek hukum yang berbenturan dengan subjek hukum lainnya. Namun kadangkalanya penegak hukum sering gagal paham dengan dua sistem hukum ini, yang tidak dapat membedakan mana yang pidana dan mana yang perdata, sehingga mencampur adukkan antara kasus perdata yang dijadikan kasus pidana dan kasus pidana dijadikan kasus perdata dengan berbagai alasan.
\end{abstract}

Kata kunci: Unsur pidana, Penguasaan tanah, Sertifikat

\section{A. Pendahuluan}

Istilah perdata dan pidana adalah dua jenis hukum yang sering didengar, namun sebenarnya apa yang dimaksud dengan hukum pidana dan hukum perdata? Bagaimana batasan di antara keduanya? Dapatkah kasus penguasaan tanah tanpa ada tanda bukti hak menjadi perkara pidana? Pada dasarnya, hukum yang berlaku di Indonesia menganut sistem hukum Eropa Kontinental. Adapun yang menjadi sumber hukum dalam sistem hukum ini adalah undang-undang yang dibentuk oleh pemegang kekuasaan legislatif, aturan-aturan yang dibuat oleh pemegang kekuasaan eksekutif (berdasarkan wewenang yang ditetapkan undang-undang), dan kebiasaan-kebiasaan yang hidup dan diterima sebagai hukum oleh masyarakat. Berdasarkan sumber inilah, sistem hukum Eropa Kontinental kemudian dibagi ke dalam dua golongan, yakni bidang hukum publik dan bidang hukum privat yakni.

Pertama, hukum publik: Merupakan bidang hukum yang memiliki ruang lingkup urusan subjek hukum yang tengah bersengketa dengan objek hukum (hukum yang telah ada). Atau dalam kata lain, hukum publik merupakan bidang hukum dengan cakupan peraturan-peraturan hukum yang mengatur kekuasaan dan wewenang penguasa negara serta hubungan antara masyarakat dan negara. Adapun jenis hukum yang termasuk dalam ranah hukum publik ialah hukum tata negara, hukum administrasi negara, dan hukum pidana. Menurut Moeljanto hukum pidana merupakan E-ISSN: 2657-0300 Lembaga Penelitian dan Penerbitan Hasil Penelitian Ensiklopedia 83 P-ISSN: 2657-0319 
bagian dari pada keseluruhan hukum yang berlaku di suatu negara yang mengadakan dasar-dasar dan aturan-aturan untuk: a) menentukan perbuatan-perbuatan mana yang tidak boleh dilakukan dan yang dilarang, dengan disertai ancaman atau sanksi yang berupa pidana tertentu bagi barang siapa yang melanggar larangan tersebut; b) menentukan kapan dan dalam hal-hal apa kepada mereka yang telah melanggar larangan-larangan itu dapat dikenakan atau dijatuhi pidana sebagaimana yang telah diancamkan; dan c) menentukan dengan cara bagimana pengenaan pidana itu dapat dilaksanakan apabila ada orang yang disangka telah melanggar larangan tersebut.

Adapun berdasarkan rumusan hukumnya, hukum pidana dibedakan menjadi dua, yakni hukum pidana materiil dan hukum pidana formal. Hukum pidana materiil (substantive criminal law) adalah serangkaian peraturan hukum atau perundangundangan yang menetapkan perbuatan-perbuatan apa saja yang dapat dihukum atau dilarang untuk dilakukan, siapa saja yang dapat dijatuhi hukuman atas tindakan tersebut, dan hukuman apa saja yang dapat diberikan pada subjek yang melanggar serta hal-hal apa saja yang dapat mejadi pengecualian berlakunya penerapan hukum ini. Hukum pidana formal (hukum acara pidana) adalah serangkaian ketentuan hukum yang mengatur tata pelaksanaan atau penerapan hukum pidana materill dalam implementasinya. Atau dalam definisi lain, hukum pidana formal merupakan segala ketentuan terkait prosedur penuntutan pihak-pihak yang diduga melakukan perbuatan pidana ke muka pengadilan.

Kedua, Hukum privat atau yang juga disebut dengan hukum perdata, merupakan bidang hukum yang memiliki ruang lingkup urusan subjek hukum yang tengah berbenturan dengan subjek hukum lainnya. Atau dalam kata lain, hukum privat alias hukum perdata merupakan bidang hukum yang mengatur urusan antar individu dalam melaksanakan hak dan kewajibannya. Di Indonesia hukum perdata juga terbagi menjadi hukum perdata materiil dan hukum perdata formal.

Hukum perdata materiil, merupakan hukum yang berisi ketentuan-ketentuan yang mengatur kepentingan perseorangan, yakni: 1) Hukum pribadi (personenrecht) ; Hukum yang berisi ketentuan dan peraturan soal hak dan kewajiban manusia dalam bertindak sebagai subjek hukum; 2) Hukum keluarga (familierecht) ; Hukum yang berisi ketentuan dan peraturan tentang hal-hal terkait kekeluargaan: hubungan lahir dan batin antara pihak-pihak yang terlibat perkawinan (suami dan istri serta anak). Hal-hal yang menjadi cakupan hukum keluarga adalah keturunan, kekuasaan orang tua, perwalian, pendewasaan, pengampunan (curatele), dan perkawinan; 3) Hukum kekayaan (vermogensrecht) ; Hukum yang berisi ketentuan dan peraturan tentang hakhak perolehan seseorang dalam kaitannya dengan orang lain yang memiliki nilai uang (hubungan hukum yang dapat dinilai dengan uang). Bila membahas tentang kekayaan seseorang, maka yang dimaksud adalah jumlah dari hak dan kewajiban orang tersebut yang dinilai dengan uang; dan 4) Hukum waris (erfecht)Hukum yang berisi ketentuan dan peraturan tentang pemindahan hak milik seseorang yang telah meninggal dunia kepada pihak-pihak lain yang berhak menerima hak tersebut.

Hukum perdata formal, adalah sekumpulan peraturan perundang-undangan yang mengatur pelaksanaan sanksi bagi para pelaku yang melanggar hak-hak keperdataan sesuai yang dimaksud dalam hukum perdata materiil. 


\section{B. Metodologi Penelitian}

Penulisan karya ilmiah ini, berjenis penelitian hukum normatif (yuridis normatif), yaitu penelitian perpustakaan yang mengkaji studi dokumen menggunakan berbagai data sekunder seperti peraturan perundang-undangan, keputusan pengadilan, teori hukum dan dapat berupa pendapat para sarjana.

\section{Hasil dan Pembahasan}

Sesungguhnya tidak ada Surat Edaran Mahkamah Agung (SEMA) yang melarang penyidik Polri menangani laporan dari masyarakat tentang dugaan kasus pidana jika tuntutan perdata sedang diperiksa di pengadilan. Selain itu, SEMA tidak mempunyai kekuatan untuk melarang penyidik Polri. Pasal 12 ayat (3) UU No. 1 Tahun 1950 Tentang Susunan, Kekuasaan dan Jalan Pengadilan Mahkamah Agung Indonesia. Mahkamah Agung berhak memberi peringatan-peringatan, teguran dan petunjuk yang dipandang perlu dan berguna kepada pengadilan-pengadilan dan para Hakim, baik dengan surat tersendiri maupun dengan surat edaran. Sehingga surat edaran MA hanya berlaku untuk internal pengadilan dan para hakim, tidak sampai mengatur ke penyidik Polri.

Namun beda halnya dengan Peraturan Mahkamah Agung No. 1 Tahun 1956. dalam pasal 1 Perma tersebut dinyatakan; Apabila pemeriksaan perkara pidana harus diputuskan hal adanya suatu hal perdata atas suatu barang atau tentang suatu hubungan hukum antara dua pihak tertentu, maka pemeriksaan perkara pidana dapat dipertangguhkan untuk menunggu suatu putusan Pengadilan dalam pemeriksaan perkara perdata tentang adanya atau tidak adanya hak perdata itu. Jadi, apabila ada suatu perkara pidana yang harus diputuskan mengenai suatu hal perdata atau ada tentang suatu hubungan hukum antara dua pihak tertentu, pemeriksaan perkara pidana tersebut dapat ditangguhkan, menunggu putusan Pengadilan.

Penundaan perkara pidana tersebut juga dapat didasarkan pada yurisprudensi MA, putusan No. 628 K/Pid/1984. Dalam putusan ini, MA memerintahkan Pengadilan Tinggi Bandung untuk menunggu adanya putusan pengadilan yang berkekuatan hukum tetap, yang memutuskan mengenai status kepemilikan tanah. Sehingga jika perkara berupa hak atas kepemilikan tanah atau bangunan, maka pidana yang menyangkut hal itu harus dipending dahulu. Ini juga sesuai dengan surat edaran Kejagung dengan jelas ditegaskan jika sekiranya kasus yang objeknya berupa tanah, di mana status hukum kepemilikan tanah berdasarkan alasan hak yang dimiliki masih berperkara perdata di pengadilan atau sama-sama belum memiliki sertifikat tanah, maka jika ada pihak yang dituduh melanggar pidana, maka kasus tersebut tidak dapat dipidana.

Ada empat peraturan yang diduga dilawan jika melanjutkan perkara pidana yakni Peraturan Mahkamah Agung (PERMA) RI nomor 1 tahun 1956 dan Surat Edaran MA (SEMA) RI nomor 4 tahun 1980 dan surat panduan dalam sistem penuntutan yang dikeluarkan oleh Kejagung nomor B-230/E/Ejp/01/2013 tanggal 22 Januari 2013, serta Peraturan Kapolri (Perkap) Pasal 61 dan 62.

Maka untuk itu sebelum pihak penyidik Kepolisian Negara Republik Indonesia melanjutkan ke ketahap selanjutnya, Perkara Perdata tidak bisa dipaksakan ke Ranah Pidana jika masalah perdatanya menyangkut sengketa kepemilikan tanah atau bangunan belum jelas status hukum kepemilikan berdasarkan atas hak yang kuat dan sah, maka harus dipastikan dulu status kepemilikan melalui gugatan Perdata/TUN.

Sesuai dengan Surat dikeluarkan Kejaksaan Agung No : B-230/E/Ejp/01/2013 Tgl 22 Januari 2013.

- Dimana juga harus mempedomani Pasal 81 KUHP dan Pasal 81 KUHAP

E-ISSN: 2657-0300 Lembaga Penelitian dan Penerbitan Hasil Penelitian Ensiklopedia 
- PERMA No 1 Tahun 1956.

- SEMA No 4 tahun 1980.

- Putusan-putusan MA No 413/K/KR/1980 tanggal 26 Agustus Jo Putusan MA No 129K/Kr/1979 tanggal 16 April 1980 Jo Putusan MA No 628K/Pid/1984 tanggal 22 Juli 1985

Harus dibedakan sengketa tanah antara para pihak yang sama-sama belum memiliki sertifikat sebagai bukti hak atas tanah dengan sengketa tanah yang telah bersertifikat. Obyek tanah yang belum bersertifikat terlebih dahulu harus dibuktikan berdasarkan putusan pengadilan dalam perkara perdata. Sedangkan obyek tanah yang telah bersertifikat telah mempunyai kepastian hukum yakni kepastian hak atas tanah dan kepastian surat ukur menyangkut letak dan batas-batas tanah sehingga tidak perlu menunggu putusan pengadilan tentang siapa yang berhak.

Berdasarkan ketentuan Pasal 32 ayat (1) PP no 24 tahun 1997 tentang pendaftaran tanah. Sertipikat merupakan surat tanda bukti hak yang berlaku sebagai alat pembuktian yang kuat mengenai data fisik dan data yuridis yang termuat di dalamnya, sepanjang data fisik dan data yuridis tersebut sesuai dengan data yang ada dalam surat ukur dan buku tanah hak yang bersangkutan. Ketentuan tersebut mengandung makna bahwa obyek tanah yang telah bersertipikat tidak dapat diragukan lagi tentang kebenaran subyek/pemilik dan obyek tanah yang tertera pada sertipikat.

Berdasarkan asas praesumptio iustae causa atau rechtmatig heid, setiap keputusan pejabat selalu harus dianggap sah (rechtmatig heid) sebelum ada pembatalan. Asas ini tersurat dan tersirat dalam ketentuan pasal 67 ayat (1) UU No. 5 Tahun 1986, yang menyatakan gugatan tidak menunda pelaksanaan Keputusan Tata Usaha Negara yang digugat sebelum ada pembatalan.

Makna dari ketentuan tersebut adalah setiap keputusan pejabat in casu sertifikat hak atas tanah tidak serta merta batal atau status quo ketika proses gugatan berlangsung. Dengan kata lain sertipikat bukti hak atas tanah tetap berlaku sebagai bukti kepemilikan yang sah walaupun sedang dalam proses sengketa perdata di pengadilan.

Maka sudah jelas apa saja perbuatan yang termasuk dalam tindak pidana dan perdata. Selama perbuatan subjek hukum bertentangan dengan hal-hal yang merupakan objek hukum (sesuai hukum perdata materiil), maka perkara tersebut dapat dipidanakan. Sementara itu, setiap perbuatan subjek hukum yang bertentangan dengan subjek hukum lainnya (hubungan antar individu maupun golongan) akan menjadi ranah perkara perdata.

Namun demikian, tidak jarang kasus perdata dibuat seolah-olah menjadi kasus tindak pidana. Sebenarnya kasus perdata tidak akan bisa berubah menjadi kasus pidana. Kecuali bila dalam prosesnya terjadi perubahan kasus perdata yang ditindaklanjuti di lembaga peradilan sebagai delik pidana, hal ini tidak berarti kedudukan kasus tersebut berubah. Alasan munculnya delik pidana yang diproses adalah tidak lain karena pada dasarnya ditemukan unsur tindak pidana yang memang terjadi dalam kasus perdata yang tengah diperkarakan. contoh kasus utang piutang, secara hukum utang piutang sudah jelas menjadi ranah hukum perdata. Kendati demikian dalam kenyataannya, apabila dalam perjalanannya ditemukan bukti penipuan, maka barulah kasus tersebut dapat diproses secara pidana. 


\section{Penutup}

Sengketa tanah antara individu dengan individu yang sama-sama belum memiliki sertifikat sebagai bukti hak, sama sekali belum ada unsur pidanya, kecuali salah satu pihak telah memilki alas hak setifikat tanah yang memungkin pihak lain melakukan pidana dengan cara menguasai tanah pihak yang telah bersertifikat. Tanah bersertifikat telah mempunyai kepastian hukum hak atas tanah dan kepastian surat ukur menyangkut letak dan batas-batas tanah sehingga tidak perlu menunggu putusan pengadilan tentang siapa yang berhak. Sedangkan obyek tanah yang belum bersertifikat terlebih dahulu harus dibuktikan berdasarkan putusan pengadilan dalam perkara perdata. Namun kadangkala bagi penegak hukum yang gagal paham perbedaan hukum yang memiliki sertifikat dengan yang tidak memiliki sertifikat, seringkali tetap melanjutkan ketahap hukum lanjutan.

\section{Daftar Pustaka}

Emeritus John Gilissen, Emeritus Frits Gorle. Sejarah Hukum Suatu Pengantar. Refika Aditama, Bandung 2009.

H. Salim, HS,SH, MS. Perkembangan Teori Dalam Ilmu Hukum. PT Raja Grafindo Persada 2009.

Satcipto Rahardjo, Hukum dan Perilaku (Hidup Baik Adalah Dasar Hukum Yang Baik), Kompas Media Nusantara Jakarta 2009.

H. Salim, HS,SH, MS. Perkembangan Teori Dalam Ilmu Hukum. PT Raja Grafindo Persada 2009.

Undang-Undang No. 1 Tahun 1950 Tentang Susunan, Kekuasaan dan Jalan Pengadilan Mahkamah Agung Indonesia.

PERMA RI Nomor 1 tahun 1956 dan Surat Edaran MA (SEMA) RI nomor 4 tahun 1980.

Surat dikeluarkan Kejaksaan Agung No : B-230/E/Ejp/01/2013 Tgl 22 Januari 2013. Peraturan Kapolri (Perkap) Pasal 61 dan 62.

https://megapolitan.okezone.com/read/2015/02/11/338/1104580/perkara-perdata-takbisa-dipaksakan-ke-ranah-pidana. 